\title{
THE MARINE MACROALGAE OF BRIER ISLAND, NOVA SCOTIA, CANADA*
}

\author{
DAVID J. GARBARY ${ }^{* * *}$, CAROLYN J. BIRD ${ }^{2}$, \\ BEVERLY HYMES ${ }^{3}, \&$ HERB VANDERMEULEN ${ }^{4}$ \\ ${ }^{1}$ Jack McLachlan Laboratory of Aquatic Plant Resources, \\ St. Francis Xavier University, Antigonish, Nova Scotia, B2G 2W5, Canada \\ ${ }^{2}$ P.O. Box 9, Chester Basin, Nova Scotia, B0J 1KO, Canada \\ ${ }^{3}$ Dalhousie University, Department of Biology, 1355 Oxford Street, \\ Halifax, Nova Scotia, B3H 4R2, Canada \\ ${ }^{4}$ Bedford Institute of Oceanography, \\ Dartmouth, Nova Scotia, B2Y 4A2, Canada
}

\begin{abstract}
From May to October 2017 seaweeds were identified in the field and laboratory from 20 sites around Brier Island, Nova Scotia. While most sites were intertidal rocky shores, there were one small salt marsh and one eelgrass bed included in the study, and some subtidal sampling was conducted utilizing SCUBA and snorkeling. The Brier Island seaweeds comprised 152 species and varieties of which 62 were Rhodophyta, 44 were Chlorophyta, 44 were Phaeophyceae, and two species were Xanthophyceae. Three species were new records for eastern Canada: Colaconema bonnemaisoniae, C. endophyticum, and Elachista stellaris, all were previously recorded from New England. The flora included eight nonnative species of which Colpomenia peregrina and Bonnemaisonia hamifera (both gametophytic and tetrasporophytic stages) were abundant at two or more sites, and the invasive Codium fragile subsp. fragile was recorded based on a single drift specimen. With 150 species and varieties of seaweeds, Brier Island has the highest species richness of a limited area of eastern Canada. The Cheney floristic index at 2.4 is higher than comparable areas, and suggests that many additional brown algae remain to be found.

Keywords: Chlorophyta, Colaconema, Bay of Fundy, Brier Island, Phaeophyceae, Rhodophyta, seaweeds
\end{abstract}

\section{INTRODUCTION}

Brier Island, Nova Scotia $\left(44^{\circ} 15^{\prime} \mathrm{N}, 66^{\circ} 22^{\prime} \mathrm{W}\right)$ is the most westerly point in Nova Scotia, at the end of Digby Neck and Long Island, in

* We dedicate this paper to three pioneers of the seaweed flora of the Maritime Provinces: Tikvah Edelstein, Constance MacFarlane, Jack McLachlan

** Author to whom correspondence should be addressed: dgarbary@gmail.com 
the outer Bay of Fundy. A portion is under management by the Nature Conservancy of Canada as part of an effort to preserve native habitat of the globally endangered Geum peckii Pursh ${ }^{1}$ (Rosaceae). With its highly exposed location in the Bay of Fundy, a largely undisturbed shoreline, and a diversity of habitats, a baseline study of Brier Island provides a baseline for long-term monitoring of impacts of sea level rise, climate change and invasive organisms. Here we provide a floristic study of the marine macroalgae carried out in 2017.

The marine macroalgal flora of Brier Island was initially investigated by Edelstein et al. (1970) as part of a detailed floristic and seasonal study of Digby Neck and adjacent Long and Brier Islands. While the Brier Island flora was not treated separately, the subsequent review of seaweed distributions for the Bay of Fundy by Wilson et al. (1979) included 66 species on Brier Island including 30 Rhodophyta, 9 Chlorophyta and 27 Phaeophyceae. No comprehensive account of the algae followed, although more focused observations of individual species and single sites were undertaken as part of more geographically wide-ranging studies. For example, Novaczek and McLachlan (1989) carried out a single transect on Brier Island at North Point as part of transects on rocky intertidal shores of the Maritime provinces, although the results for Brier Island were merged with those of other sites in the outer Bay of Fundy. Further physiological and ecological studies were carried out on Palmaria palmata (e.g. Garbary et al. 2012), Prasiola stipitata (Kang et al. 2014); Ascophyllum nodosum and Vertebrata lanosa (Garbary 2017a); and Prasiola crispa (Garbary and Hill 2017). There are complementary floristic studies from the western side of the Bay of Fundy in both Canada and USA. These include South et al.(1986) for Passamaquoddy Bay, Bates et al. (2009) for coastal New Brunswick, Mathieson et al. (2009) for Cobscook Bay, Maine, and Mathieson (2018) for northeastern ('downeast') Maine. Here we present a list of the seaweeds of Brier Island based on sampling from May to October 2017, and discuss our findings in the context of seaweed distributions in the Maritime Provinces and adjacent northeastern United States. This new species list provides a detailed account for an area that has received little attention for about 50 years.

Authorities for species are provided in the text only when they are not included in Appendix 1. 


\section{MATERIALS AND METHODS}

Brier Island has a circumference of about $24 \mathrm{~km}$ (Fig 1). It has a boreal climate, and as a consequence of being surrounded by the cold waters and large tides of the Bay of Fundy, its maritime climate tends to have cooler summers and milder winters than the rest of Nova Scotia. The island is sparsely settled with a single community of Westport (population ca. 220), where economic activity focuses on fishing and ecotourism. Much of the terrestrial landscape consists of secondary growth of boreal forest (mostly black spruce) undergoing secondary succession from abandoned agricultural and logging activity. There are extensive peatlands, some of which are inhabited by Geum peckii. The western side of the island has a fringe of coastal heaths in which the invasive Rosa rugosa Thunberg has become dominant and is outcompeting both herbaceous and shrubby vegetation on the coastal fringe (Garbary et al. 2013).

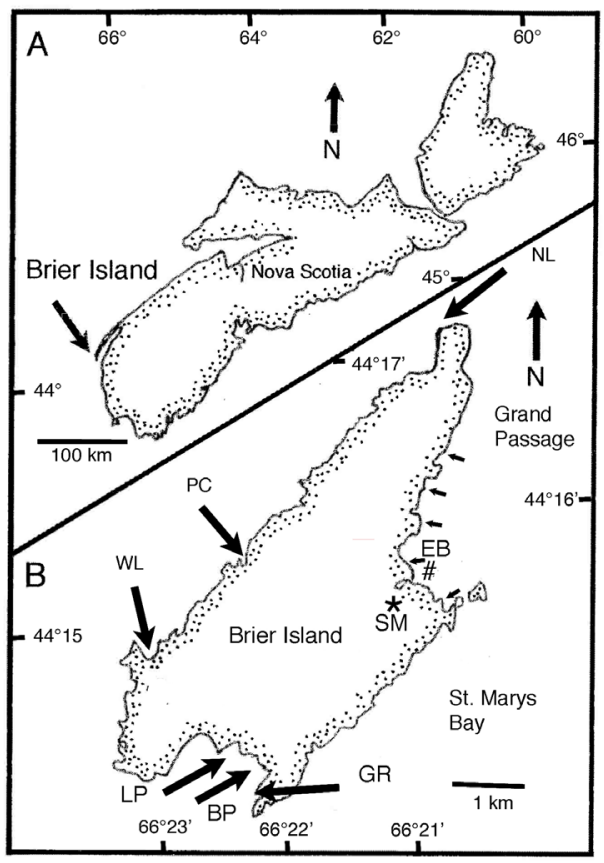

Fig 1 Map of Nova Scotia (A) and Brier Island (B) indicating primary collection sites. Abbreviations and symbols: NL, Northern Light; PC, Pero Jack Cove; WL, Western Light; LP, Little Pond Cove; BP, Big Pond Beach; GR, Gull Rock Point; SM, salt marsh*; EB, eelgrass bed\#; small arrows, Westport Village. 
Table 1 Primary sites on Brier Island sampled for seaweed biodiversity and sampling dates. Primary sites were visited multiple times on low tides. Secondary sites were visited once on poor tide, or by SCUBA. Coordinates indicate approximate midpoint on the shore, taken from Google Earth. Primary sites listed counter-clockwise from Northern Light. See Fig 1 for locations. All sampling times are from 2017.

\begin{tabular}{|c|c|c|c|}
\hline Site & $\begin{array}{l}\text { Latitude } \\
\left({ }^{\circ} \mathbf{N}\right)\end{array}$ & $\begin{array}{l}\text { Longitude } \\
\left({ }^{\circ} \mathbf{W}\right)\end{array}$ & $\begin{array}{l}\text { Dates sampled } \\
\text { (day/month) }\end{array}$ \\
\hline \multicolumn{4}{|l|}{ Primary sites } \\
\hline Northern Light & $44^{\circ} 19.19^{\prime}$ & $66^{\circ} 20.64^{\prime}$ & $\begin{array}{l}13 / 5,2 / 6,23 / 6,27 / 7, \\
2 / 9,6 / 10\end{array}$ \\
\hline Pero Jack Cove & $44^{\circ} 15.97^{\prime}$ & $66^{\circ} 22.07^{\prime}$ & $24 / 6$ \\
\hline Western Light & $44^{\circ} 14.94^{\prime}$ & $66^{\circ} 23.46^{\prime}$ & $1 / 6,22 / 6,25 / 7,7 / 10$ \\
\hline Little Pond Cove & $44^{\circ} 14.35^{\prime}$ & $66^{\circ} 22.71^{\prime}$ & $11 / 5,25 / 6,26 / 7,28 / 8,8 / 10$ \\
\hline Big Pond Cove & $44^{\circ} 14.35^{\prime}$ & $66^{\circ} 22.28^{\prime}$ & $12 / 5,24 / 6,6 / 10$ \\
\hline $\begin{array}{l}\text { Gull Rock Point } \\
\text { (east side Big Pond Cove) }\end{array}$ & $44^{\circ} 14.15^{\prime}$ & $66^{\circ} 22.22^{\prime}$ & $29 / 7$ \\
\hline Grand Passage (Westport) & $44^{\circ} 15.90^{\prime}$ & $66^{\circ} 20.95$ & $\begin{array}{l}10 / 5,21 / 6,22 / 6,26 / 6 \\
23 / 7,28 / 7,31 / 8,8 / 10\end{array}$ \\
\hline Westport eelgrass* & $44^{\circ} 15.62^{\prime}$ & $66^{\circ} 20.94^{\prime}$ & $23 / 7,27 / 8^{\#}, 29 / 8^{\#}, 7 / 10$ \\
\hline Westport salt marsh* & $44^{\circ} 15.56^{\prime}$ & $66^{\circ} 21.15^{\prime}$ & $4 / 6,22 / 7,6 / 10$ \\
\hline \multicolumn{4}{|l|}{ Secondary sites } \\
\hline North of Pero Jack Cove & $44^{\circ} 16.30^{\prime}$ & $66^{\circ} 21.99^{\prime}$ & $13 / 5$ \\
\hline Westport, floating dock ${ }^{1}$ & $44^{\circ} 15.50^{\prime}$ & $66^{\circ} 20.84^{\prime}$ & $21 / 6$ \\
\hline Hog Cove & $44^{\circ} 13.92^{\prime}$ & $66^{\circ} 22.23^{\prime}$ & $21 / 6$ \\
\hline Peters Island ${ }^{\#}$ & $44^{\circ} 15.52^{\prime}$ & $66^{\circ} 20.19^{\prime}$ & $27 / 8$ \\
\hline Gull Rock ${ }^{\#}$ & $44^{\circ} 11.28^{\prime}$ & $66^{\circ} 25.21^{\prime}$ & $28 / 8$ \\
\hline Whipple Point ${ }^{\#}$ & $44^{\circ} 14.38^{\prime}$ & $66^{\circ} 22.96^{\prime}$ & $28 / 8$ \\
\hline Gull Rock ${ }^{\#}$ & $44^{\circ} 12.29^{\prime}$ & $66^{\circ} 23.90^{\prime}$ & $28 / 8$ \\
\hline Northwest ledges ${ }^{\#}$ & $44^{\circ} 21.09^{\prime}$ & $66^{\circ} 21.77^{\prime}$ & $29 / 8$ \\
\hline Seal Cove ${ }^{\#}$ & $44^{\circ} 17.26^{\prime}$ & $66^{\circ} 20.75^{\prime}$ & $29 / 8$ \\
\hline Gull Rock (east side) ${ }^{\#}$ & $44^{\circ} 12.80^{\prime}$ & $66^{\circ} 23.10^{\prime}$ & $30 / 8$ \\
\hline Gull Rock (west side) ${ }^{\#}$ & $44^{\circ} 12.84^{\prime}$ & $66^{\circ} 23.32^{\prime}$ & $30 / 8$ \\
\hline North Point (east side) & $44^{\circ} 16.90^{\prime}$ & $66^{\circ} 20.46^{\prime}$ & $3 / 9$ \\
\hline
\end{tabular}

* Coordinates from centre of habitat/site

\# DFO SCUBA sampling

${ }^{1}$ floating dock pulled ashore - unknown provenance

The bedrock is the endpoint of a basalt ridge that extends 200 $\mathrm{km}$ along much of the southern shore of the Bay of Fundy (Roland 1982). The intertidal zones (Tables 1,2) are mostly exposed basalt bedrock and boulder fields (Fig 2) with numerous rock pools (Fig 3). The shores include steep cliffs rising about $10 \mathrm{~m}$ above the intertidal zone, gently sloping shores comprising boulder fields, a single sandy beach, and some muddy-gravel shores associated with the village of Westport. A salt marsh (ca.2 ha) on the landward side of the main road at Westport is part of the drainage from the eutrophic Big Meadow 
Table 2 Summary of primary physical features of sampling sites. Width of site refers to portion of shore explored. Site length refers to length of intertidal zone.

\begin{tabular}{|c|c|c|c|c|}
\hline Site & $\begin{array}{l}\text { Width of } \\
\text { site } \\
\text { (m) }\end{array}$ & $\begin{array}{l}\text { Site } \\
\text { length } \\
\text { (m) }\end{array}$ & $\begin{array}{l}\text { Primary } \\
\text { subtrata }\end{array}$ & Comments \\
\hline Northern Light & 180 & 140 & $\begin{array}{l}\text { Boulder fields, } \\
\text { bedrock, tidal } \\
\text { pools }\end{array}$ & $\begin{array}{l}\text { Most wave-exposed } \\
\text { site }\end{array}$ \\
\hline Pero Jack Cove & 80 & 100 & $\begin{array}{l}\text { Boulder field, } \\
\text { bedrock, } \\
\text { freshwater inflow }\end{array}$ & \\
\hline Western Light & 50 & 75 & $\begin{array}{l}\text { Boulder field, } \\
\text { bedrock }\end{array}$ & $\begin{array}{l}\text { Extensive platform } \\
\text { at low water, } \\
\text { protected by islets } \\
\text { and headlands }\end{array}$ \\
\hline Little Pond Cove & 100 & 500 & $\begin{array}{l}\text { Boulder field, } \\
\text { bedrock, numerous } \\
\text { shallow pools }\end{array}$ & $\begin{array}{l}\text { Protected by ridges } \\
\text { of basalt bedrock }\end{array}$ \\
\hline Big Pond Cove & 400 & NA & $\begin{array}{l}\text { Sandy gravel beach } \\
\text { with some cobble }\end{array}$ & $\begin{array}{l}\text { Visited for wrack } \\
\text { collection }\end{array}$ \\
\hline Gull Rock point & 200 & 60 & $\begin{array}{l}\text { Boulder field with } \\
\text { low pools }\end{array}$ & \\
\hline $\begin{array}{l}\text { Grand Passage } \\
\text { (Westport) }\end{array}$ & 1500 & $\begin{array}{l}50- \\
100 \mathrm{~m}\end{array}$ & $\begin{array}{l}\text { Boulder fields, mud, } \\
\text { wood pilings, } \\
\text { concrete walls, } \\
\text { floating dock }\end{array}$ & Low wave-exposure \\
\hline $\begin{array}{l}\text { Westport eelgrass } \\
\text { bed }\end{array}$ & $>100$ & NA & $\begin{array}{l}\text { Eelgrass in muddy } \\
\text { sand }\end{array}$ & $\begin{array}{l}\text { Requires spring } \\
\text { tides }\end{array}$ \\
\hline $\begin{array}{l}\text { Westport salt } \\
\text { marsh }\end{array}$ & 100 & 150 & $\begin{array}{l}\text { Marsh mud/peat, } \\
\text { sides of drainage } \\
\text { channel, high pools } \\
\text { with floating mats }\end{array}$ & $\begin{array}{l}\text { Limited tidalmarsh } \\
\text { exchange } \\
\text { via culvert }\end{array}$ \\
\hline
\end{tabular}

Bog into the ocean. In addition, two tiny remnants of salt marsh (each ca. $20 \times 10 \mathrm{~m}$ ) of Spartina alterniflora Loisel. remain on the seaward side where Big Meadow Bog drains into Grand Passage via a culvert. A single bed of Zostera marina occurs in the low intertidal and shallow subtidal zone at Westport (Fig 1) and is bounded on the seaward side by an active salmon aquaculture facility. Artificial substrata of concrete at the government wharf and ferry terminal, a floating dock in the main harbour, and numerous pilings associated with the fishing industry wharfs and fish shacks provide extensive wood substrata. Remnant pilings from the destruction caused by the 

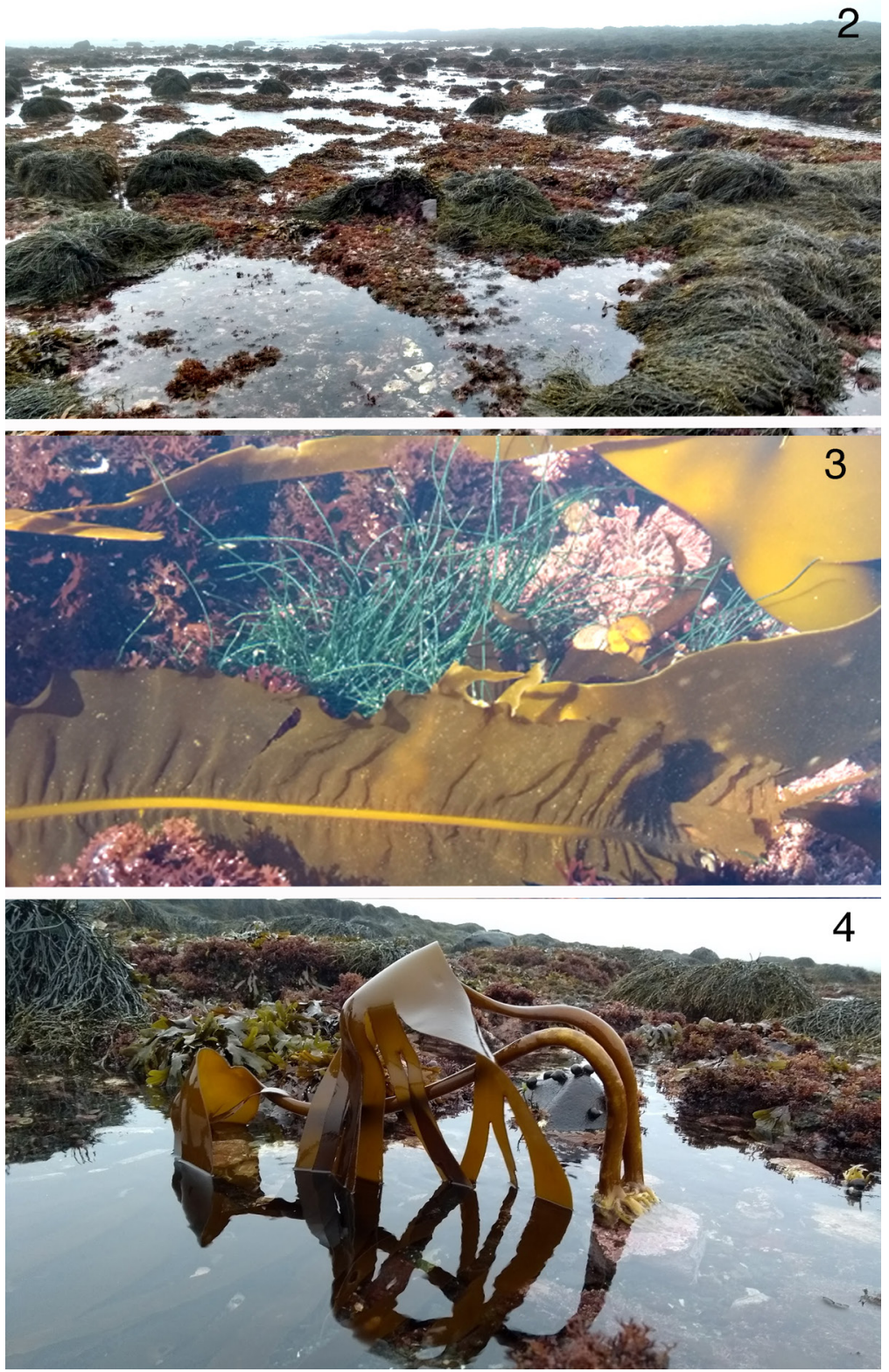

Figs 2-4 Selected intertidal habitats for macroalgal collections. (2) Shore at Little Pond Cove at low tide with numerous shallow pools. (3) Mid-shore rock pool at Northern Light with diversity of algae including: Alaria esculenta (with midrib), Chaetomorpha melagonium (green hair), and Corallina officinalis (calcified pink alga). (4) Low intertidal rock pool at Northern Light with Laminaria digitata and diverse algae in background. 
February 2, 1976 Groundhog Day gale are also scattered along the shorefront of Westport.

Marine algae were collected between May and October 2017 around Brier Island (Fig 1, Table 1). The primary sites (i.e., Western Light, Little Pond Cove, Big Pond Cove, Northern Light, Westport shore and eelgrass bed) were visited multiple times. One to three people visited a site on a tide and attempted to collect all of the species present. Field work was carried out such that collections were undertaken during periods that overlapped with spring tides. Many conspicuous algae were simply noted in the field at each site, and general collections were returned to a field laboratory on Brier Island to identify species requiring microscopic evaluation, and to examine large plants for epiphytic and endophytic taxa. Algae were typically processed while fresh, with voucher specimens prepared for deposit in regional herbaria at ACAD and STFX. Microscopic species were prepared as semi-permanent slides in $40 \%$ clear corn syrup. Subtidal collections were carried out by snorkeling at low water in July, and some additional collections were made in late August-early September by SCUBA divers from the Department of Fisheries and Oceans collecting at $c a .10 \mathrm{~m}$ depth (Table 1). We use the floristic index of Cheney [1977; = (\#green algae + \# red algae) / \# brown algae] to compare other regional floras.

Mathieson and Dawes (2017) was the primary resource for keys and descriptions, although Brodie et al. (2007) was especially useful for green algae, Bird and McLachlan (1992) for red algae, and Fletcher (1987) for brown algae. Keys in Sears (1998) and Villalard-Bohnsack (2003) were also useful. Authorities for all algal species identified are given Appendix 1.

\section{RESULTS}

Over 1,100 identifications of 152 species and varieties of marine and brackish water macroalgae were recorded from Brier Island (Appendix 1). These species included 62 Rhodophyta, 44 Chlorophyta and 44 Phaeophyceae and two species of Vaucheria (Xanthophyceae). Of these species, over 35 were new for Digby Neck, 12 were new for the Bay of Fundy, one was new for Nova Scotia, and three were new records for Canada (Table 3). 
Table 3 New distribution records for Brier Island and associated geographic areas.

\begin{tabular}{|c|c|c|c|c|}
\hline Species & $\begin{array}{l}\text { Eastern } \\
\text { Canada }\end{array}$ & $\begin{array}{l}\text { Bay of } \\
\text { Fundy }\end{array}$ & $\begin{array}{l}\text { Digby } \\
\text { Neck }\end{array}$ & Comment \\
\hline
\end{tabular}

\section{Chlorophyta}

Blidingia subsalsa?

Capsosiphon fulvescens

Chaetomorpha picquotiana

Chlorochytrium cohnii

Cladophora liniformis

Codium fragile subsp. fragile

Derbesia marina

Eugomontia sacculata

Percursaria percursa

Prasiola crispa

Pseudendoclonium dynamenae

Pseudothrix borealis

Tellamia contorta

Ulothrix laetevirens

Ulothrix subflaccida

Ulva torta

Ulvella repens?

fucicola

\section{Rhodophyta}

Acrochaetium endozoicum

Acrochaetium humile

Acrochaetium luxurians

Acrochaetium minimum

Acrochaetium parvulum

Bonnemaisonia hamifera

Coccotylus hartzii

Colaconema bonnemaisoniae

Colaconema endophyticum

Colaconema daviesii

Erythrotrichia carnea

Lithothamnion glaciale

Pneophyllum fragile

Rhodomela lycopodioides

Rhodophysema georgii

Scagelia pylaisaei $+\quad$ Requires culturing to

distinguish from

B. ramifera (Garbary

and Barkhouse 1987)

$+$

$+$

$+$

$+$

High marsh pool;

new record for

Nova Scotia

Single drift specimen

See Garbary and

Hill (2017)

$+$

$+$

$+$

$+$

Endophyte in Elachista

Endozoic in bryozoan

Abundant

gametophytes and

tetrasporophytes

Common endophyte

in Bonnemaisonia

hamifera

Rare endophyte in

Dictyosiphon 
Table 3 Cont'd

\begin{tabular}{lllll}
\hline Species & $\begin{array}{c}\text { Eastern } \\
\text { Canada }\end{array}$ & $\begin{array}{l}\text { Bay of } \\
\text { Fundy }\end{array}$ & $\begin{array}{l}\text { Digby } \\
\text { Neck }\end{array}$ & Comment \\
\hline $\begin{array}{l}\text { Phaeophyceae } \\
\text { Colpomenia peregrina }\end{array}$ & & & & \\
$\begin{array}{l}\text { Dictyosiphon eckmannii? } \\
\text { Ectocarpus siliculosus }\end{array}$ & & + & $\begin{array}{l}\text { Abundant at several } \\
\text { sites }\end{array}$ \\
$\begin{array}{l}\text { var. pygmaeus } \\
\text { Elachista stellaris? }\end{array}$ & + & & & \\
$\begin{array}{l}\text { Sphacelaria rigidula? } \\
\text { Spongonema tomentosum }\end{array}$ & & + & + & Epiphyte on \\
Xanthophyceae & & & + & Vertebrata lanosa \\
$\begin{array}{l}\text { Vaucheria intermedia } \\
\text { Vaucheria } \text { sp. }\end{array}$ & & & & \\
\hline
\end{tabular}

Three distinct intertidal habitats were explored: 1) the rocky intertidal zone of the west side of the island, 2) the bed of Zostera in Grand Passage, and 3) the salt marsh at Westport. The majority of species occurred on the rocky intertidal of the west side (121 species with 69 exclusive species), 38 species (8 exclusive) were found in the eelgrass bed, and 15 species ( 7 exclusive) were found in the salt marsh (Appendix 1). Two species, Melanosiphon intestinalis and Peyssonnelia rosenvinge $i$ were found only on artificial structures in Westport village; the former was associated with an old piling north of the ferry terminal, and the latter grew on concrete at the ferry terminal.

Following the species concepts in Garbary et al. (1982) and Mathieson and Dawes (2017) we indentified two endophytic algae for the first time in eastern Canada: Colaconema endophyticum and C. bonnemaisoniae (Figs 5, 7). Both species were previously recorded in the northwestern Atlantic Ocean only south of Cape Cod (Mathieson and Dawes 2017). The former species had very small cells ( $<10 \mu \mathrm{m}$ long) and the single parietal chloroplasts were devoid of pyrenoids. The latter species had much larger cells (15-30 $\mu \mathrm{m})$, each with a single parietal chloroplast and pyrenoid. C. endophyticum was found once in Dictyosiphon foeniculaceus in the subtidal zone south of Northern Light on the Fundy shore. C. bonnemaisoniae was more common and observed ten times in the gametophytic phase of Bonnemaisonia hamifera, and was particularly conspicuous in the cell walls of the hooked branches of its host when host tissue was 

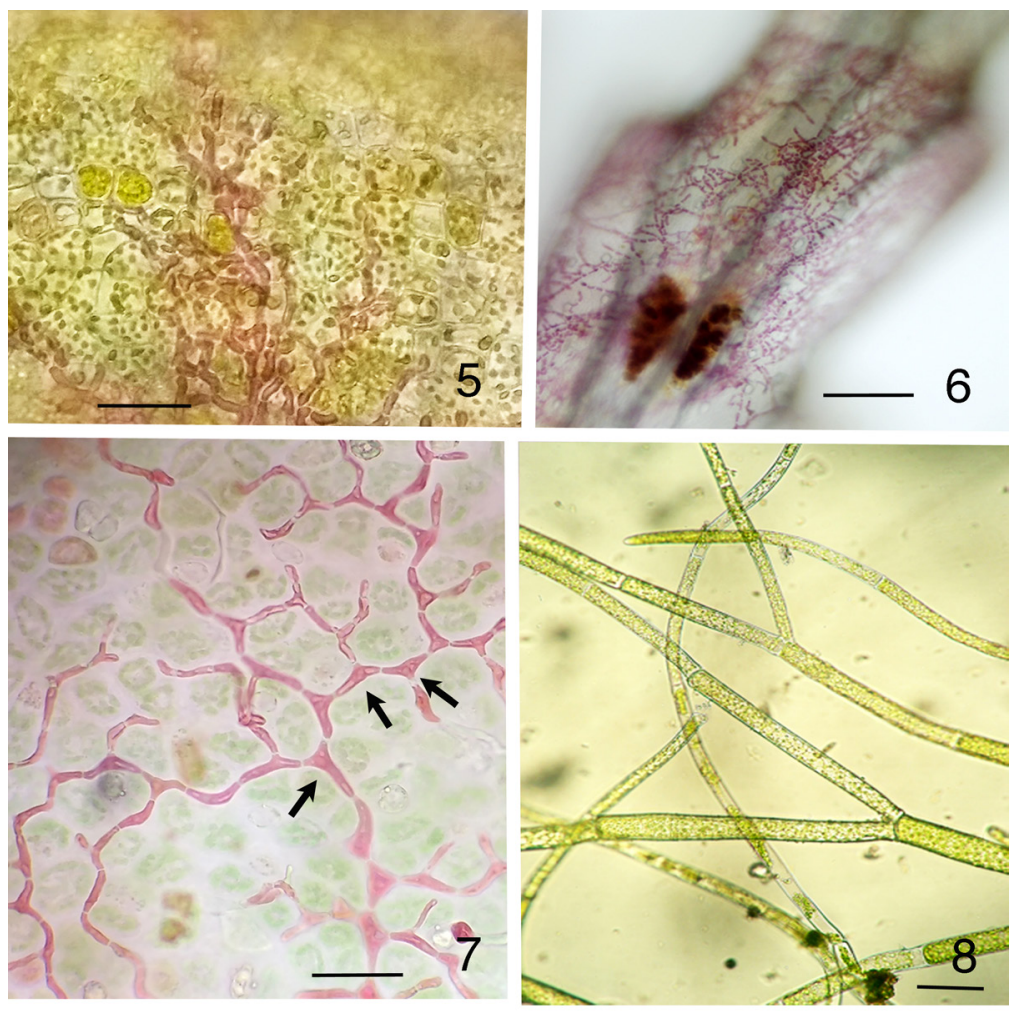

Figs 5-8 Photomicrographs of selected endophytic red algae (Figs 5-7) and a free-living green alga. (5) Colaconema endophytica in outer cell wall of Dictyosiphon foeniculaceus. Scale bar $=20 \mu \mathrm{m}$. (6) Acrochaetium endozoicum in bryozoan. Scale bar $=100 \mu \mathrm{m}$. (7) Colaconema bonnemaisoniae endophytic in outer wall of Bonnemaisonia hamifera; arrows indicate single pyrenoid in each cell. Scale bar $=25 \mu \mathrm{m}$. (8) Cladophora liniformis in high salt marsh pool. Scale bar $=100 \mu \mathrm{m}$,

bleached or senescent. While no attempt was made to quantify the occurrence of $C$. bonnemaisoniae, only a few specimens of the host gametophytes were required to find the endophyte. Accordingly, it probably is fairly common. Another endobiotic species is the rare Acrochaetium endozoicum (Fig 6). It occurred in a bryozoan epiphytic on Chaetomorpha melagonium in a low shore rock pool. This was only the second record of this species in Canada. The single previous Canadian record is from the sublittoral of Halifax County (Edelstein et al. 1969).

The identification of Elachista stellaris was somewhat problematic as the identification keys are based primarily on host identity. 
Our material was a common epiphyte on Vertebrata lanosa and was identified seven times in the collections. The thalli were very small relative to E. fucicola, and only 1-2 mm high. A single clump of the host sometimes had five or six thalli. In both Europe and North America, E. stellaris is reported from a variety of hosts but neither Ascophyllum nor Fucus which are regarded as the only hosts for E. fucicola (Fletcher 1987, Mathieson and Dawes 2017). Host switching of E.fucicola onto V. lanosa remains a possibility.

Two species of Vaucheria were present in the salt marsh: V.intermedia and Vaucheria sp., which, in the absence of gametangia, could not be identified to species. Its narrow filaments (ca. $20 \mu \mathrm{m})$ and the absence of reproduction suggest V. minuta Blum \& Conover, but further collections are needed to confirm this identification (see Mathieson and Dawes 2017).

Cladophora liniformis (Fig 8) formed an extensive floating mat in a high pool in the salt marsh at Westport, where it was the dominant species and mixed with Ulva torta (new for Digby Neck). C. liniformis was not previously recorded from Nova Scotia, and previous records from eastern Canada were questioned by South (1984).

\section{DISCUSSION}

\section{Species richness in the Maritime Provinces and Gulf of Maine}

The 152 species and varieties of seaweeds identified on Brier Island in 2017 indicate a relatively diverse flora in a limited geographic area. The Brier Island flora thus represents $60 \%$ the 254 species of red, brown and green seaweeds for the Bay of Fundy reported by Wilson et al. (1979) for New Brunswick and Nova Scotian shores to Cape Sable Island (Table 4). This difference in species richness is explained by the much larger area and greater diversity of habitats in the Bay of Fundy as a whole. In addition, the Wilson et al. inventory included historical collections made over more than 50 years; thus, the greater likelihood of including rare taxa.

A primary objective of this work was to compare the current flora of Brier Island to that detailed by Edelstein et al. (1970) based largely on collections from Digby Neck, with only limited sampling undertaken on Brier Island. The species identified in that study and other incidental collections on Brier Island in the ensuing years were mapped by Wilson et al. (1979). While the algal distributions 


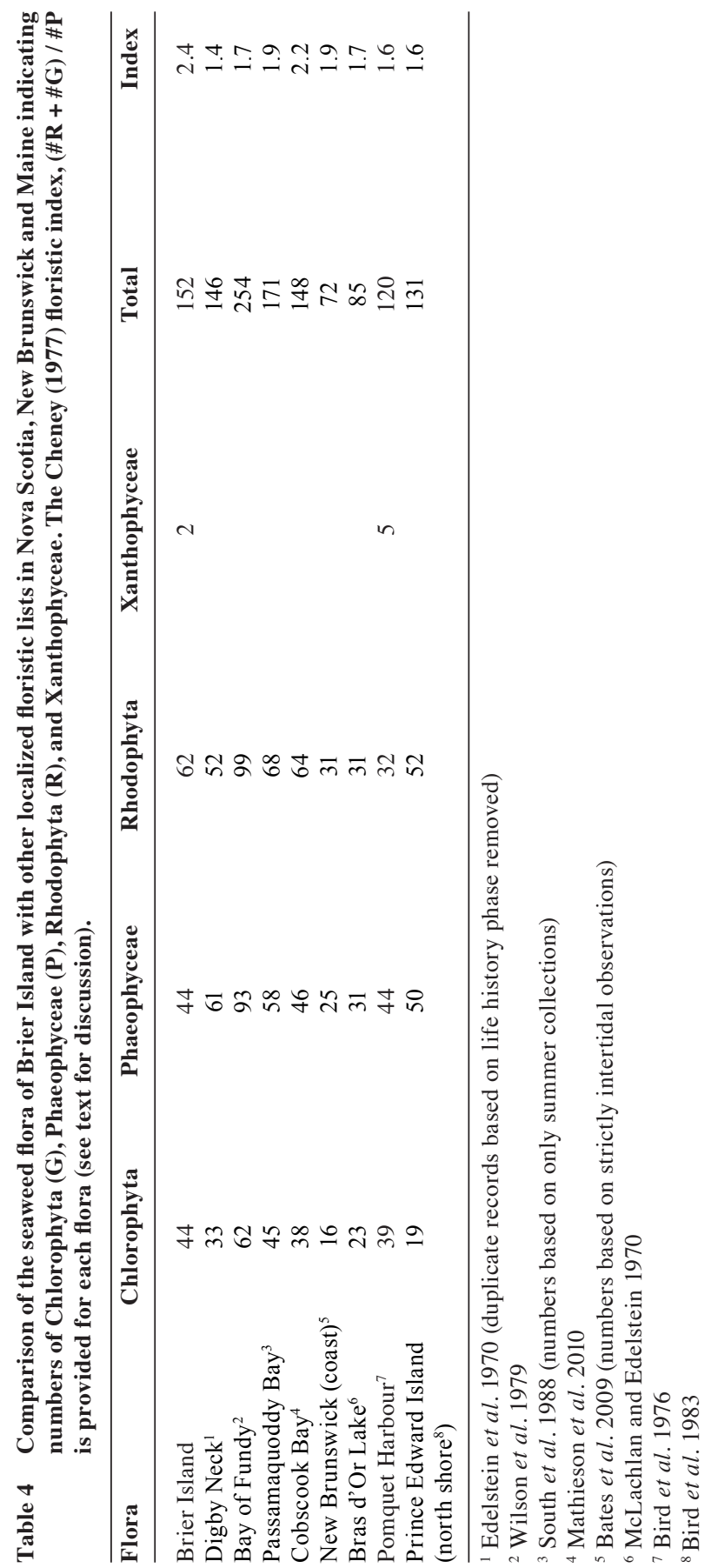


reported by Edelstein et al. (1970) for Brier Island (as given in Wilson et al. 1979) were clearly limited because of collection intensity, many of those species can reasonably be expected to occur on Brier Island today. This list includes five brown algae: Punctaria tenuissima (C.Agardh) Greville [as Desmotrichum undulatum (J.Agardh) Reinke], Entonema polycladum (Jaasund) Jaasund, Eudesme virescens (Carmichael ex Berkeley) J.Agardh, Microspongium globosum Reinke, and Myriotrichia clavaeformis Harvey (as M. filiformis Harvey). A sixth species Stragularia clavata (Harvey) Hamel (as Ralfsia bornetii Kuckuck) is now considered the sporophytic phase of Scytosiphonaceae (see Mathieson and Dawes 2017). In addition, one green alga, Ulva rigida C.Agardh, and three red algae, Harveyella mirabilis (Reinsch) F.Schmitz \& Reinke, Hydrolithon farinosum (J.V.Lamouroux) Penrose and Y.M.Chambelain, and Leptophytum leave Adey were listed. Most of these algae could reasonably be expected to occur on Brier Island. Of these, Hydrolithon farinosum is typically found as an epiphyte on Zostera marina Linnaeus during fall and winter (Mathieson and Dawes 2017), for which we had only limited collections.

South et al. (1988) reported 176 species from Passamaquoddy Bay. While this was more than the 150 species we found on Brier Island, theirs was over a collection area at least several orders of magnitude greater, and encompassing habitats (e.g., estuaries) not found on Brier Island. Their study was also based on extensive subtidal sampling via SCUBA with experienced phycologist-divers including a specialist on crustose coralline algae. Moreover, the total for that list included many species that were not found specifically in the study area but were assumed to be present based on reports from the outer Bay of Fundy. While more species might be found on Brier Island with winter collections and more extensive subtidal sampling, our number of summer species is unlikely to be significantly increased.

The bed of $Z$. marina has endured two major environmental impacts since the 1970s that could well have limited species richness. The first was storm damage from the Groundhog Day gale (2/2/1976) that destroyed the waterfront of Westport and sent seawater across $3 \mathrm{~km}$ of the island through the low-lying Big Meadow Bog. This would have severely impacted the eelgrass bed. Subsequently, a salmon aquaculture facility was installed adjacent to the Z marina bed, with possible effects on trophic levels. The extensive diatom growth we observed on leaf blades may have limited colonisation of 
epiphytic macroalgae. Even in its current state, Z. marina provided a habitat for 38 species, mostly as leaf epiphytes. The single collection of Derbesia marina was an unattached mat from within the eelgrass bed. Should storm action or sea-level rise cause a major breach in the barrier beach at Big Pond Cove, this would create a large area suitable for colonisation by Z. marina and its epiphytes.

Some species not recorded for Brier Island relative to the Edelstein et al. (1970) inventory may result from algal seasonality. Hence Porphyra linearis Greville, Ulvella parasitica (Oltmanns) R.Nielsen, C.J.O'Kelly \& B.Wysor (as Acrochaete), and Chlorochytrium dermatocolax Reinke were found only in the winter, and probably explains why these species were not found in the current study.

In Nova Scotia and the southern Gulf of St. Lawrence, three additional species lists of marine algae have been compiled for limited geographic areas: Bras d'Or Lake, Pomquet Harbour, and the north shore of Prince Edward Island (Table 4). All have lower diversity (85 to 131 species) even though Bras d'Or Lake and Prince Edward Island have much greater coastal areas. Only Cobscook Bay in Maine, with a much larger shoreline, has an equivalent species richness to Brier Island (148 vs 152).

The Cheney (1977) index for the floras in Table 4 ranges from 1.6 to 2.4 , suggesting that these floras are all boreal, with cold-water affinities. It is of note that Brier Island has the highest value (2.4) with Cobscook Bay close at 2.2. This suggests that the Brier Island flora is underrepresented in brown algae. The inventories of species in Edelstein et al. (1970) and Wilson et al. (1979) recorded from Digby Neck that were not found in the current study include ten green algae, 24 brown algae, and nine red algae. Should all of these species occur as well on Brier Island it would raise the species number to 184, more than the 176 species from Passamaquoddy Bay on the opposite side of the Bay of Fundy. In addition, it would lower the Cheney index to 1.8 , consistent with other regional floras.

\section{Introduced seaweeds}

Mathieson and Dawes (2017) provided a list of 32 introduced species for the northwest Atlantic Ocean. Seven of these were found on Brier Island: Codium fragile subsp. fragile, Colpomenia peregrina, Melanosiphon intestinalis, Ulonema rhizophorum, Bonnemaisonia hamifera, Ceramium secundatum, and Dumontia contorta. Several of these species appear to be naturalized (e.g., M.intestinalis, 
U. rhizophorum, Ceramium secundatum, and D. contorta) without invasive properties. The non-native, Nova Scotian invasive species, Fucus serratus Linnaeus, was not observed. The introduction and spread of F. serratus in Nova Scotia were discussed by Edelstein et al. (1971-1973), and the closest reported populations are in southwestern Nova Scotia, about $50 \mathrm{~km}$ south from Brier Island (Wilson et al. 1979).

\section{Bonnemaisonia hamifera}

There was an abundance of both the tetrasporophytic and gametophytic phases of the introduced species Bonnemaisonia hamifera (Figs 9, 10). Neither life-history stage of this species was recorded by Edelstein et al. (1970) or Wilson et al. (1979) for Digby Neck, and the nearest recorded populations were in the Yarmouth area, about $75 \mathrm{~km}$ south from Brier Island. In 2017, it would have been difficult to avoid these tetrasporophytic plants (i.e., the Trailliella-phase) in a general collection from any rocky shore on the island where it formed distinct epiphytic tufts up to several $\mathrm{cm}$ wide or occurred as scattered filaments in most rock pools. In subtidal collections, it was associated with kelp holdfasts and diverse red algae. Similarly, the gametophytic stage occurred at every site, and fragments were common in the drift or attached via their hooked branches to other macrophytes. In mid- to low-intertidal rock pools it was abundant and seemingly replaced the expected populations of Ceramium virgatum.

Chen et al.(1970) described the vegetative development of gametophytic plants directly from the Trailliella-phase, and this might account for the abundance of gametophytes on Brier Island. Alternatively, the abundance of the gametophytic phase of B. hamifera might also reflect warming of the Bay of Fundy (Hebert et al. 2018). Breeman et al. (1988) showed that the life history of B. hamifera in Europe was regulated by both temperature and daylength. Tetrasporangia formed when water temperatures were over about $11^{\circ} \mathrm{C}$ and daylength was less than $12 \mathrm{~h}$ of light. We suggest that appropriate conditions for tetrasporangial production had been reached in late summer and fall of 2016, and that the resulting tetraspores produced the gametophytes that we observed in 2017. Whereas tetrasporophytes were present in our mid-May collections, the larger gametophytic phase was not noted until late June. That is, the gametophytes that we observed appeared not to have overwintered as large plants, but must have developed in late spring to early summer. This seems inconsistent with the finding of gametophytes in winter along the Atlantic coast of Nova Scotia 

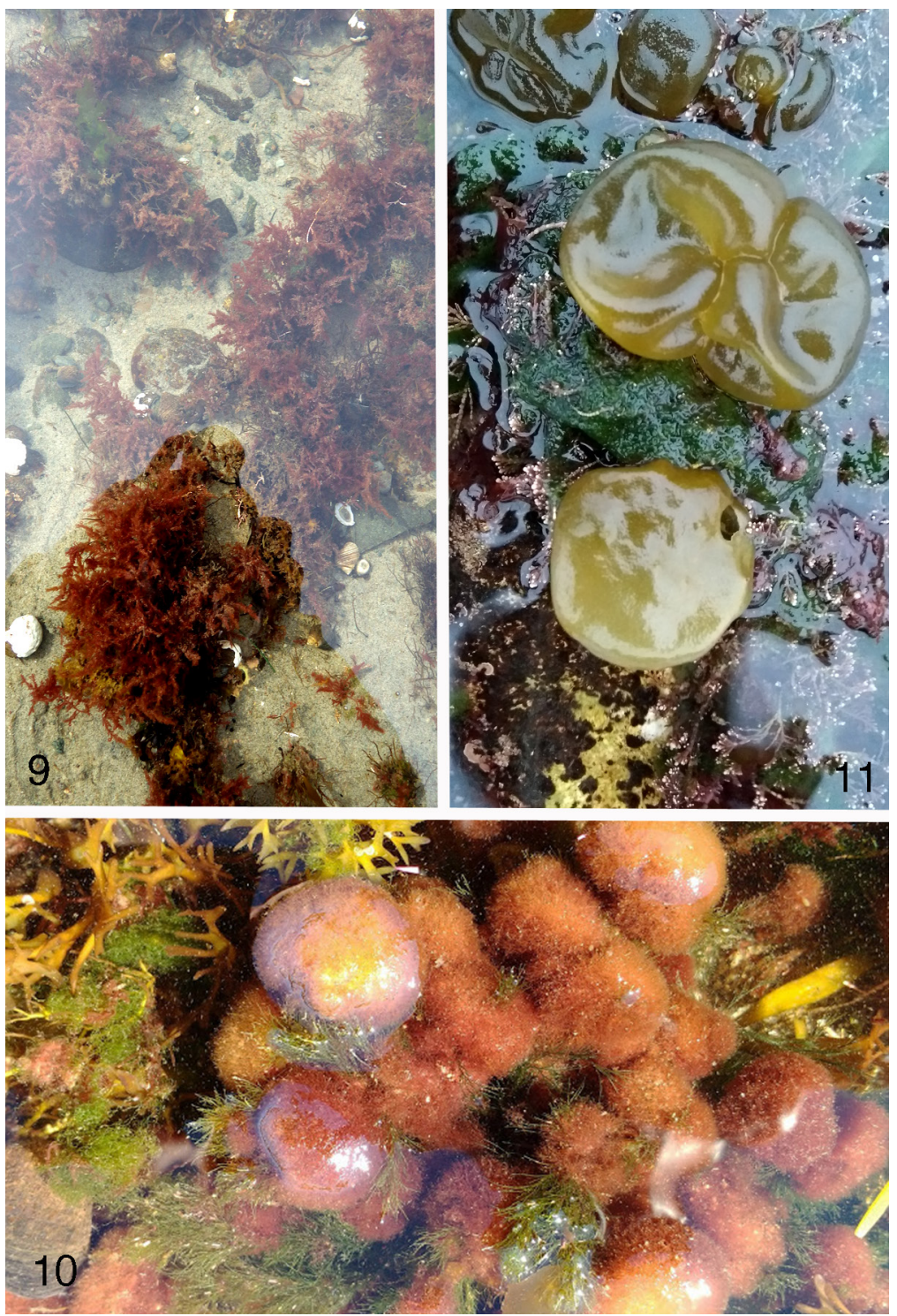

Figs 9-11 In situ photographs of two non-native species common on Brier Island. (9) Dense population of gametophytic stage of Bonnemaisonia hamifera in low intertidal rock pool (figure courtesy of Roy Gjelstad). (10) Dense population of tetrasporophytic stage (Trailiella-phase) of Bonnemaisonia hamifera in rock pool; each 'pom-pom' about $2 \mathrm{~cm}$ in diameter. (11) Two thalli of Colpomenia peregrina with larger thallus about $10 \mathrm{~cm}$ diameter. 
(Chen et al.1969). We saw no thalli with male or female gametangia, or cystocarps, although spermatangia, carpogonia and rudimentary pericarps have been recorded from Nova Scotia (Chen et al. 1969, 1970; Bird 1980). In addition, none of the tetrasporophytic thalli we observed had produced tetrasporangia by early October. In view of this, it will be interesting to see if $B$. hamifera gametophytes are as abundant in the future.

\section{Colpomenia peregrina}

Colpomenia peregrina (Fig 11) was abundant at two sites on the west side of Brier Island, at Little Pond Cove and Pero Jack Cove. It has been considered rare on the Atlantic coast of Nova Scotia (Bird and Edelstein 1978) where it was found only at a few widely separated locations, in the sublittoral zone down to 3-5 $\mathrm{m}$. It has since then become a regularly occurring species in Halifax County, where it is collected by SCUBA divers (B. Hymes pers. comm.). On Brier Island the species was found in July-August at low water on spring tides, attached to Mastocarpus stellatus and Corallina officinalis, with many thalli exposed. Thalli were up to $20 \mathrm{~cm}$ in diameter. Despite considerable wave exposure on the west side of the island, the two locations were protected from waves by offshore rock outcrops and nearby headlands. Green et al. (2012) described the southward extension of $C$. peregrina in the northwest Atlantic Ocean, and it now occurs as far south as Cape Cod. The findings on Brier Island represent an almost $100 \mathrm{~km}$ extension of the distribution from previous records in southwestern Nova Scotia. The abundance of $C$. peregrina may suggest aggressive colonization, as the species is considered a potential oyster-thief in Maine (Green et al. 2012) and the Mediterranean Sea (Verlaque et al. 2015). However, with its general lack of robustness in thallus structure, it is unlikely to become an aggressive invasive species on the exposed shores of Brier Island.

\section{Melanosiphon intestinalis}

Melanosiphon intestinalis, first reported by Edelstein et al.(1970a, b) as a new record for eastern North America from Digby Neck, is now known from Long Island (New York) to Labrador (Mathieson et al. 2008; Mathieson and Dawes 2017). On Brier Island, it was found on a single exposed piling in Westport village, and thalli were $1-2 \mathrm{~cm}$ long. One of us (CJB) recalls that this species was previously abundant on the wall of the local ferry terminal (ca. 1970). 
Extensive searches there and elsewhere on Brier Island failed to locate additional populations. In addition, thalli were mostly less than $1.5 \mathrm{~cm}$ long and about $1 \mathrm{~mm}$ wide, suggesting that the species may be on the verge of extirpation from environmental or competitive interactions.

\section{Codium fragile subsp. fragile}

Codium fragile subsp. fragile has an extensive distribution along the Atlantic coast of Nova Scotia from Yarmouth to Canso and in the southern Gulf of St. Lawrence (Watanabe et al. 2010). These distributions were likely based on independent introductions in Mahone Bay (Bird et al. 1993) and Prince Edward Island (Garbary et al. 1997, Hubbard and Garbary 2001). We found a single thallus (ca. $12 \mathrm{~cm}$ high) on the last collecting period in October amongst extensive mounds of seaweed wrack at Big Pond Cove, and none was found in four visits to Big Pond Cove in 2018. This suggests either that it had been transported a long distance as drift, or that a population on Brier Island had only recently been established. The SCUBA diving by DFO in late August/early September at eight locations found no $C$. fragile; if any populations are present, they are likely to be limited. The nearest known populations are in southwestern Nova Scotia (ca. $100 \mathrm{~km}$ from Brier Island; Watanabe et al. 2010). The species is well established in the Gulf of Maine (Mathieson et al. 2003), and the thallus on Brier Island may also have arrived via drift from northern Maine where it has been found in Cobscook Bay (Mathieson et al. 2010).

\section{CONCLUSIONS}

For its size, Brier Island possesses relatively species-rich communities of marine macroalgae in a limited geographic space. The three main community types of rocky intertidal zone, salt marsh and eelgrass beds all contribute unique species to the overall diversity of over 150 species of seaweeds. Given the relative isolation of the western shoreline of the island, and the already protected nature of key adjacent terrestrial habitats, Brier Island warrants consideration for protection of its coastal marine habitats. 
Acknowledgements Technical support in the field was provided by Roy Gjelstad and Meredith Karcz. We thank the team of scientists and divers from the Department of Fisheries and Oceans, Canada (DFO) comprising Andrew Cooper, Shelley Armsworthy, Torben Brydges and Claire Goowin for subtidal samples. Accommodation on Brier Island was provided by the Big Meadow Bog restoration project. This work was supported in part by a contract from DFO. Additional support came from research grants from the Natural Sciences and Engineering Research Council of Canada to DJG.

\section{LITERATURE CITED}

Bates, C.R., Saunders, G.W., \& Chopin, T. (2009). Historical versus contemporary measures of seaweed biodiversity in the Bay of Fundy. Botany 87: 1066-1076.

Bird, C.J. (1980). First record of female gametophytes of Bonnemaisonia hamifera Hariot (Rhodophyta, Nemaliales) in Nova Scotia. Proceedings of the Nova Scotian Institute of Science 30: 189-190.

Bird, C.J., Dadswell, M.J., \& Grund, D.W. (1993). First record of the potential nuisance alga Codium fragile ssp.tomentosoides (Chlorophyta, Caulerpales) in Atlantic Canada. Proceedings of the Nova Scotian Institute of Science 40: 11-17.

Bird, C.J., \& Edelstein, T. (1978). Investigations of the marine algae of Nova Scotia XIV. Colpomenia peregrina Sauv. (Phaeophyta: Scytosiphonaceae). Proceedings of the Nova Scotian Institute of Science 28: 181-187.

Bird, C.J., Edelstein, T., \& McLachlan, J. (1976). Investigations of the marine algae of Nova Scotia. XII. The flora of Pomquet Harbour. Canadian Journal of Botany 54: 2726-2737.

Bird, C.J., Greenwell, M., \& McLachlan, J. (1983). Benthic marine algal flora of the north shore of Prince Edward Island (Gulf of St. Lawrence), Canada. Aquatic Botany 16: 315-335.

Bird, C.J., \& McLachlan, J. (1992). Seaweed Flora of the Maritimes. 1. Rhodophyta - the Red Algae. Biopress, Bristol, UK.

Breeman, A.M., Meulenhoff, E.J.S., \& Guiry, M.D. (1988). Life history regulation and phenology of the red alga Bonnemaisonia hamifera. Helgoland Meeresuntersuchenungen 42: 535-551.

Brodie, J., Maggs, C.A., \& John, D.M. (Eds.) (2007). Green seaweeds of Britain and Ireland. British Phycological Society, Dunmurry, Northern Ireland.

Chen, L.C.-M., Edelstein, T. \& McLachlan, J. (1969). Bonnemaisonia hamifera Hariot in nature and in culture. Journal of Phycology 5: 211-220.

Chen,L.C.-M.,Edelstein, T., \& McLachlan,J.(1970). Vegetative development of the gametophyte of Bonnemaisonia hamifera from a filamentous state. Canadian Journal of Botany 48: 523-525. 
Cheney, D.F . (1977). R \& C/P - a new and improved ratio for comparing seaweed floras. Journal of Phycology 13 (suppl.): 12.

Edelstein, T., Chen, L., \& McLachlan, J. (1970). Investigations of the marine algae of Nova Scotia. VIII. The flora of Digby Neck Peninsula, Bay of Fundy. Canadian Journal of Botany 48: 621-629.

Edelstein, T., Craigie, J.S., \& McLachlan, J. (1969). Preliminary survey of the sublittoral flora of Halifax County. Journal of the Fisheries Research Board of Canada 26: 2703-2713.

Edelstein, T., Greenwell, M., Bird, C.J., \& McLachlan, J. (1971-1973). Investigations of the marine algae of Nova Scotia. X. Distribution of Fucus serratus L. and some other species of Fucus in the Maritime Provinces. Proceedings of the Nova Scotian Institute of Science 27: 33-42.

Edelstein, T., Wynne, M.J., \& McLachlan, J. (1970b). Melanosiphon intestinalis (Saund.) Wynne, a new record for the Atlantic. Phycologia 9: 5-9.

Fletcher, R.L. (1987). Seaweeds of the British Isles. Vol. 3. Fucophyceae (Phaeophyceae) Part 1. British Museum (Natural History), London, UK.

Garbary, D.J. (2017). Harvesting Ascophyllum nodosum (Phaeophyceae) reduces the abundance of its host-specific epiphyte Vertebrata lanosa. Botanica Marina 60: 297-301.

Garbary, D.J., \& Barkhouse, L.B. (1987). Blidingia ramifera stat. nov. (Chlorophyta): a new marine alga for eastern North America. Nordic Journal of Botany 7: 359-363.

Garbary, D.J., Beveridge, L.F., Flynn, A.D., \& White, K.L. 2012. Population ecology of Palmaria palmata (Palmariales, Rhodophyta) from harvested and non-harvested shores of Digby Neck, Nova Scotia, Canada. Algae 27: 33-41.

Garbary, D.J., Hansen, G.I, \& Scagel, R.F. (1982). The marine algae of British Columbia and northern Washington: Division Rhodophyta (red algae), Class Florideophyceae, Orders Acrochaetiales and Nemaliales. Syesis 15(supplement 1): 1-102.

Garbary, D.J., \& Hill, N.M. (2017). Natural history of the terrestrial green alga, Prasiola crispa (Trebouxiophyceae), and associated Herring Gulls on Brier Island, Nova Scotia. Proceedings of the Nova Scotian Institute of Science 49: 49-59.

Garbary, D.J., Hill, N.M., \& Miller, A.G. (2013). Invasion of Rosa rugosa (Rugose rose) in coastal plant communities on Brier Island, Nova Scotia. Canadian Field-Naturalist 127: 319-331.

Garbary, D.J., Vandermeulen, H., \& Kim, K-Y. (1997) Codium fragile ssp. tomentosoides (Chlorophyta) invades the Gulf of St. Lawrence, Atlantic Canada. Botanica Marina 40: 537-540.

Green, L.A., Mathieson, A.C., Neefus, C.D., Traggis, H.M., \& Dawes, C.J.(2012). Southern expansion of the brown alga Colpomenia peregrina Sauvageau (Scytosiphonales) in the northwest Atlantic Ocean. Botanica Marina 55: 643-647. 
Hebert, D., Pettipas, R., Brickman, D., \& Dever, M. (2018). Meterological, sea ice and physical oceanographic conditions on the Scotian Shelf and in the Gulf of Maine during 2016. DFO Canadian Science Advisory Secretariat Research Document 2018/016. v + 53 p.

Hubbard,C.B., \& Garbary,D.J.2002. Morphological variation of Codium fragile (Chlorophyta) in eastern Canada. Botanica Marina 45: 476-485.

Kang, E.J., Scrosati, R., \& Garbary, D.J. (2014). Physiological ecology of photosynthesis in Prasiola stipitata (Trebouxiophyceae) from the Bay of Fundy, Canada. Phycological Research 61: 208-216.

Mathieson, A.C., \& Dawes, C.J. (2017). Seaweeds of the Northwest Atlantic. University of Massachusetts Press, Amherst, Massachusetts, USA.

Mathieson, A.C., \& Dawes, C.J. (2018). A comparison of seaweed populations from Downeast Maine and eight contiguous northwest Atlantic areas. Rhodora 120: 310-380.

Mathieson, A.C., Dawes, C.J., Harris, J.G., \& Hehre, E.J. (2003). Expansion of the Asiatic green alga Codium fragile subsp.tomentosoides in the Gulf of Maine. Rhodora 105: 1-53.

Mathieson, A.C., Dawes, C.J., Hehre, E.J., \& Harris, L.G. (2009). Floristic studies of seaweed from Cobscook Bay, Maine. Northeastern Naturalist 16 (monograph 5): 1-48.

Mathieson, A.C., Pederson, J., Neefus, C.D., Dawes, C.J., \& Bray, T.K. 2008. Multiple assessments of introduced seaweeds in the northwest Atlantic. ICES Journal of Marine Science 65: 730-741.

McLachlan, J., \& Edelstein, T. (1970-1971). Investigations of the marine algae of Nova Scotia. IX. A preliminary survey of the flora of Bras d'Or Lake, Cape Breton Island. Proceedings of the Nova Scotian Institute of Science 27: 11-22.

Novaczek, I., \& McLachlan, J. (1989). Investigations of the marine algae of Nova Scotia XVII: vertical and geographic distribution of marine algae on rocky shores of the Maritime Provinces. Proceedings of the Nova Scotian Institute of Science 38: 91-143.

Roland, A.E. (1982). Geological background and physiography of Nova Scotia. Nova Scotian Institute of Science, Halifax, Nova Scotia, Canada.

Sears, J.R. [ed.] (1998). Benthic Marine Algae of the Northeastern Coast of North America from Long Island Sound to the Strait of Belle Isle. Northeast Algal Society, Dartmouth, Massachusetts, USA.

South, G.R. (1984). A checklist of marine algae of eastern Canada, second revision. Canadian Journal of Botany 62: 680-704.

South, G.R., Tittley, I., Farnham, W.F., \& Keats, D.W. (1988). A survey of the benthic marine algae of southwestern New Brunswick, Canada. Rhodora 72: 313-338.

Verlaque, M., Ruitton, S., Mineur, F., \& Boudrouresque, C.-F. (2015). CIESM atlas of exotic species in the Mediterranean. CIESM Publishers, Monaco. 
Villalard-Bohnsack, M. (2003). Illustrated Key to the Seaweeds of New England, $2^{\text {nd }}$ ed. Rhode Island Natural History Survey, Kingston, Rhode Island, USA.

Watanabe,S.,Scheibling,R.E., \& Metaxas, A. (2010). Contrasting patterns of spread in interacting invasive species: Membranipora membranacea and Codium fragile off Nova Scotia. Biological Invasions 12: 2329-2342.

Wilson, J. S., Bird, C.J., McLachlan, J., \& Taylor, A.R.A. (1979). An annotated checklist and distribution of benthic marine algae of the Bay of Fundy. Memorial University of Newfoundland Occasional Papers in Biology (No. 2), St. John's, Newfoundland, Canada. 


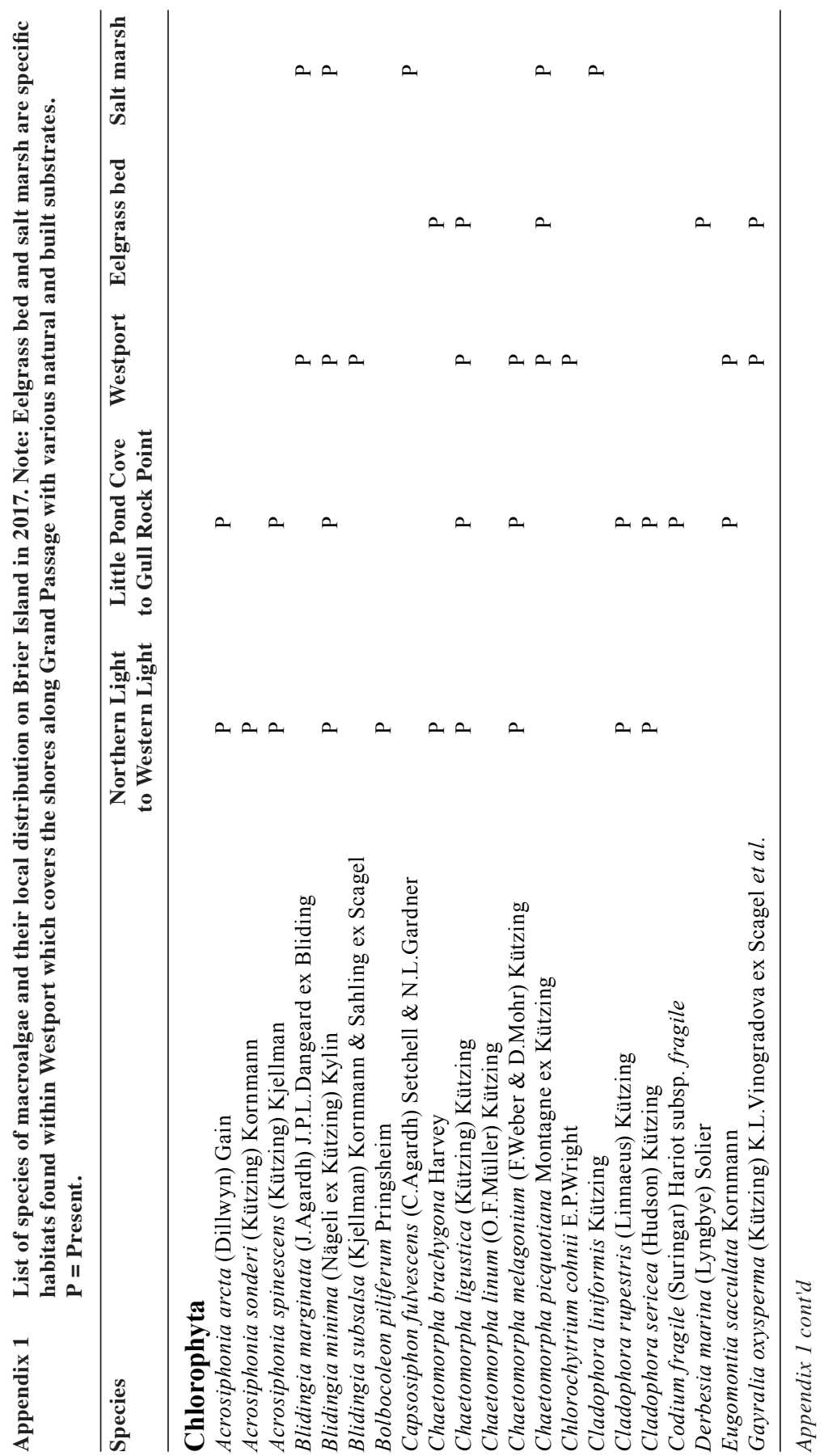




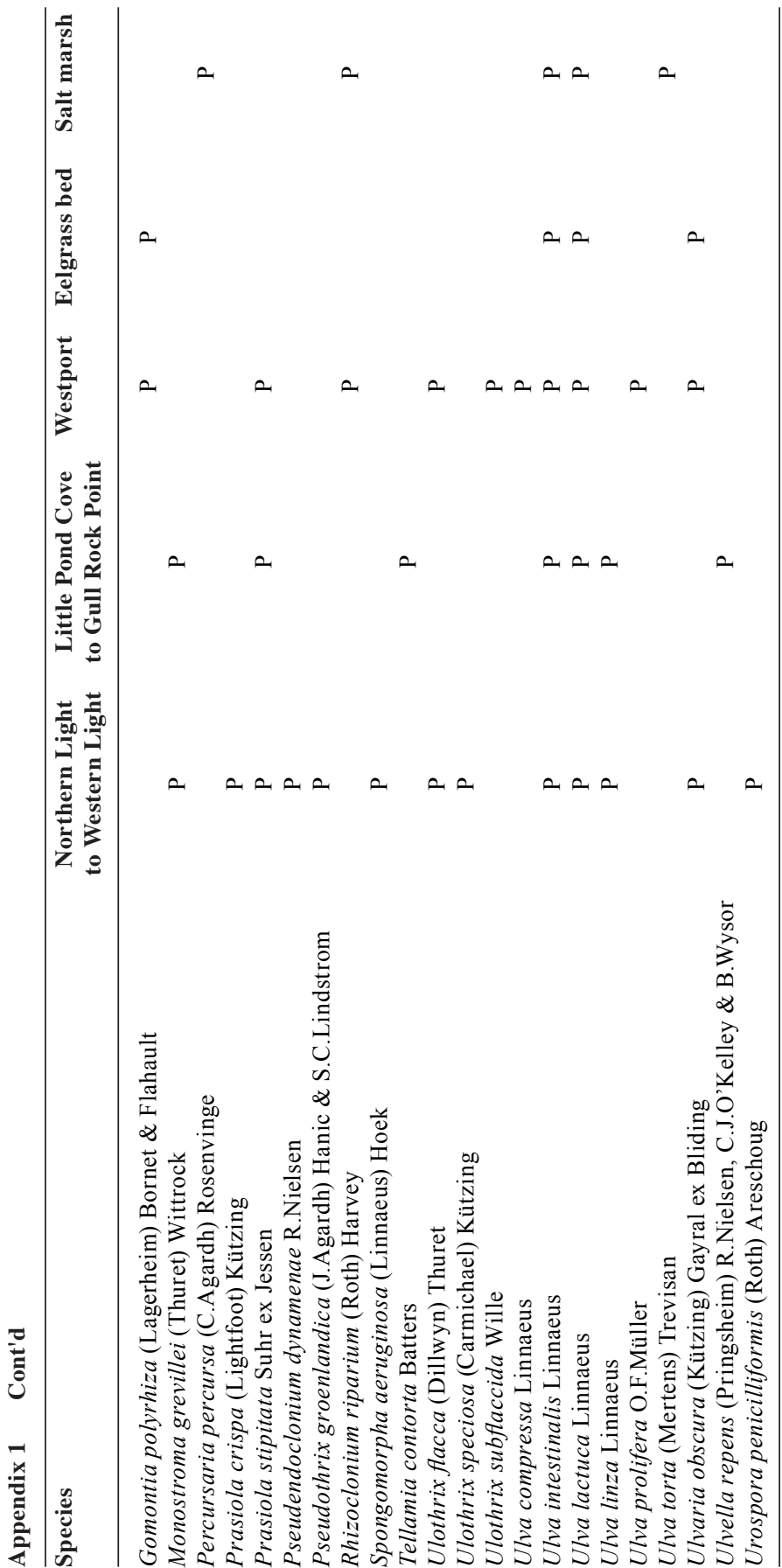




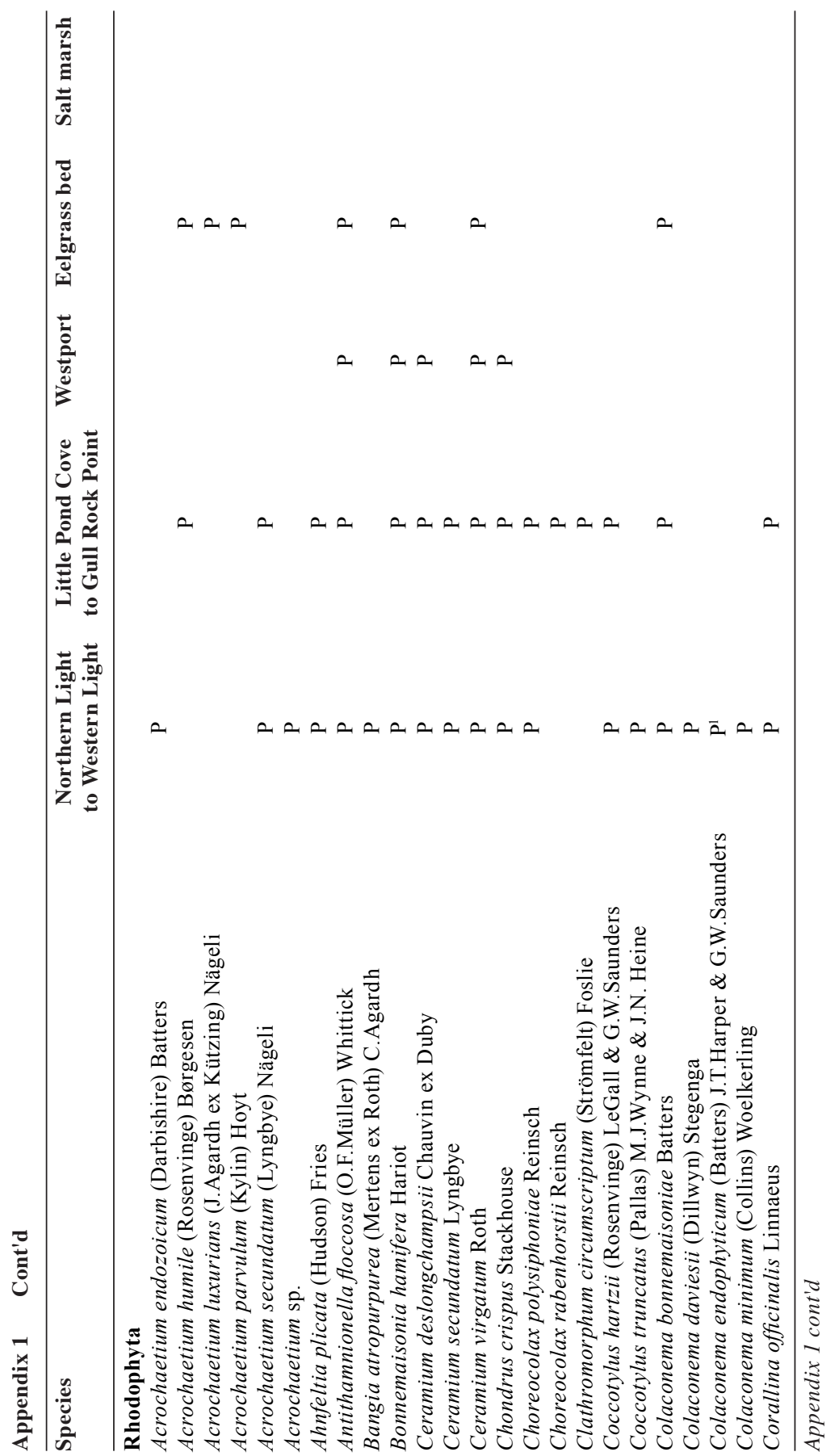




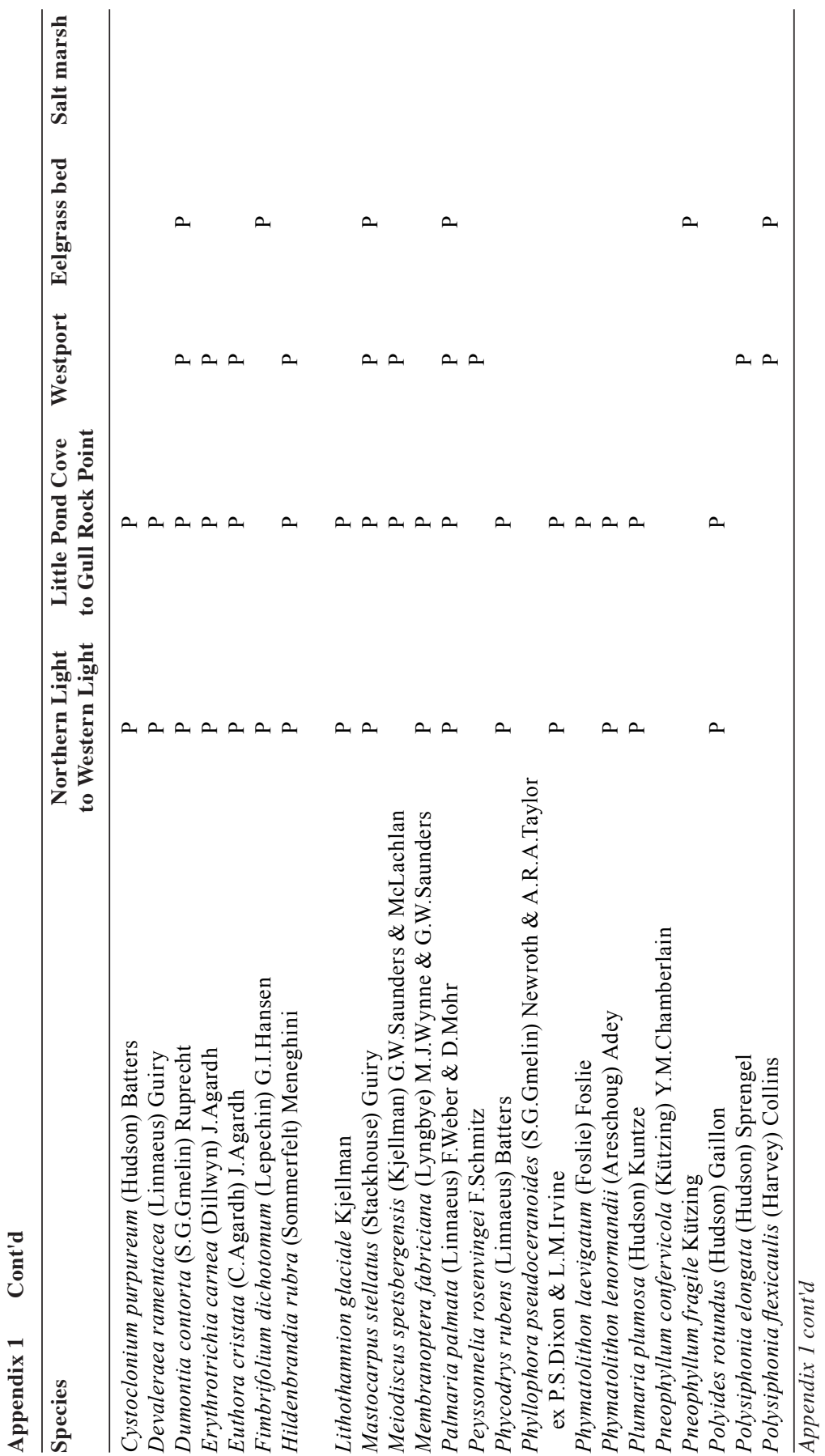




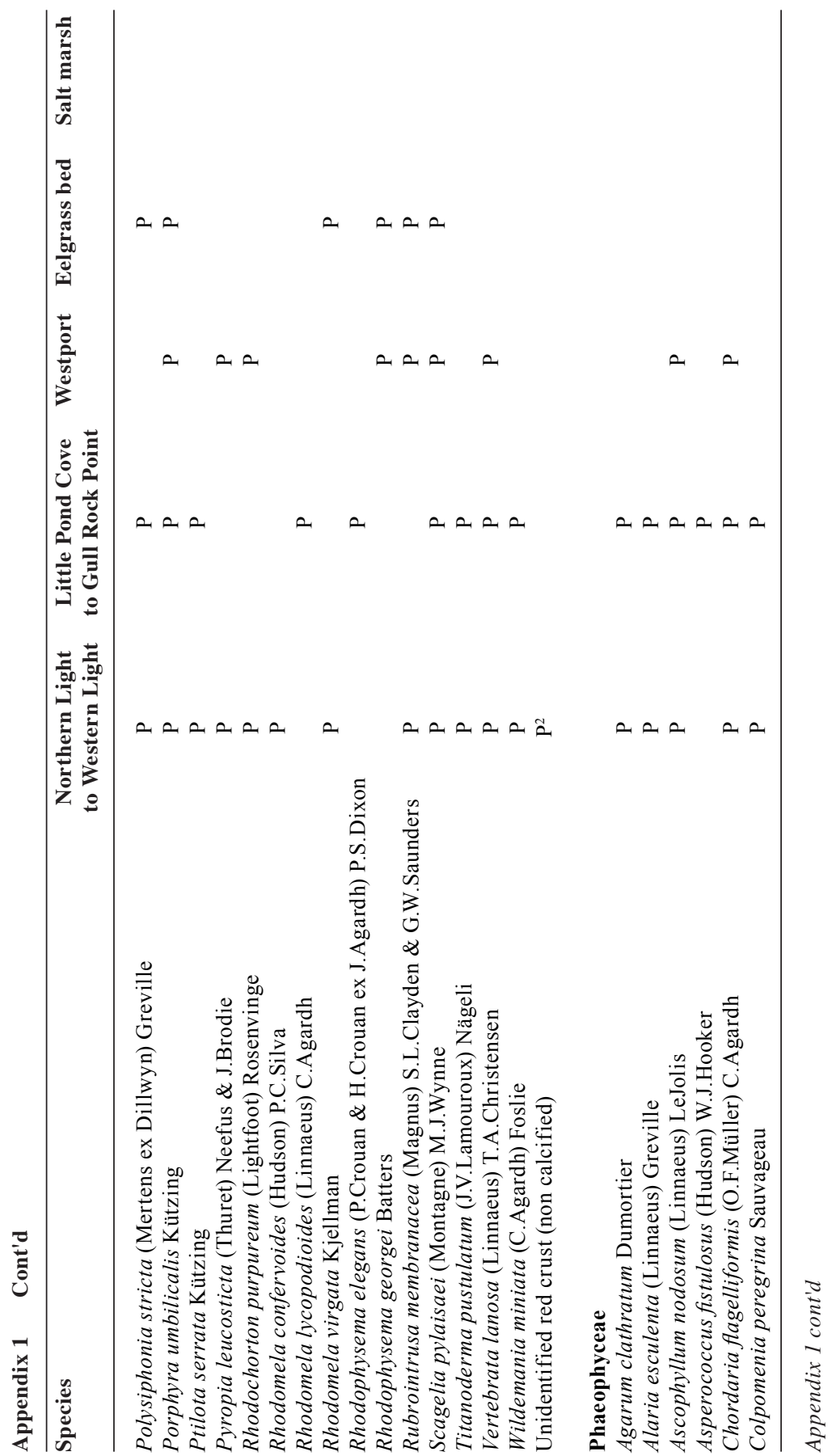




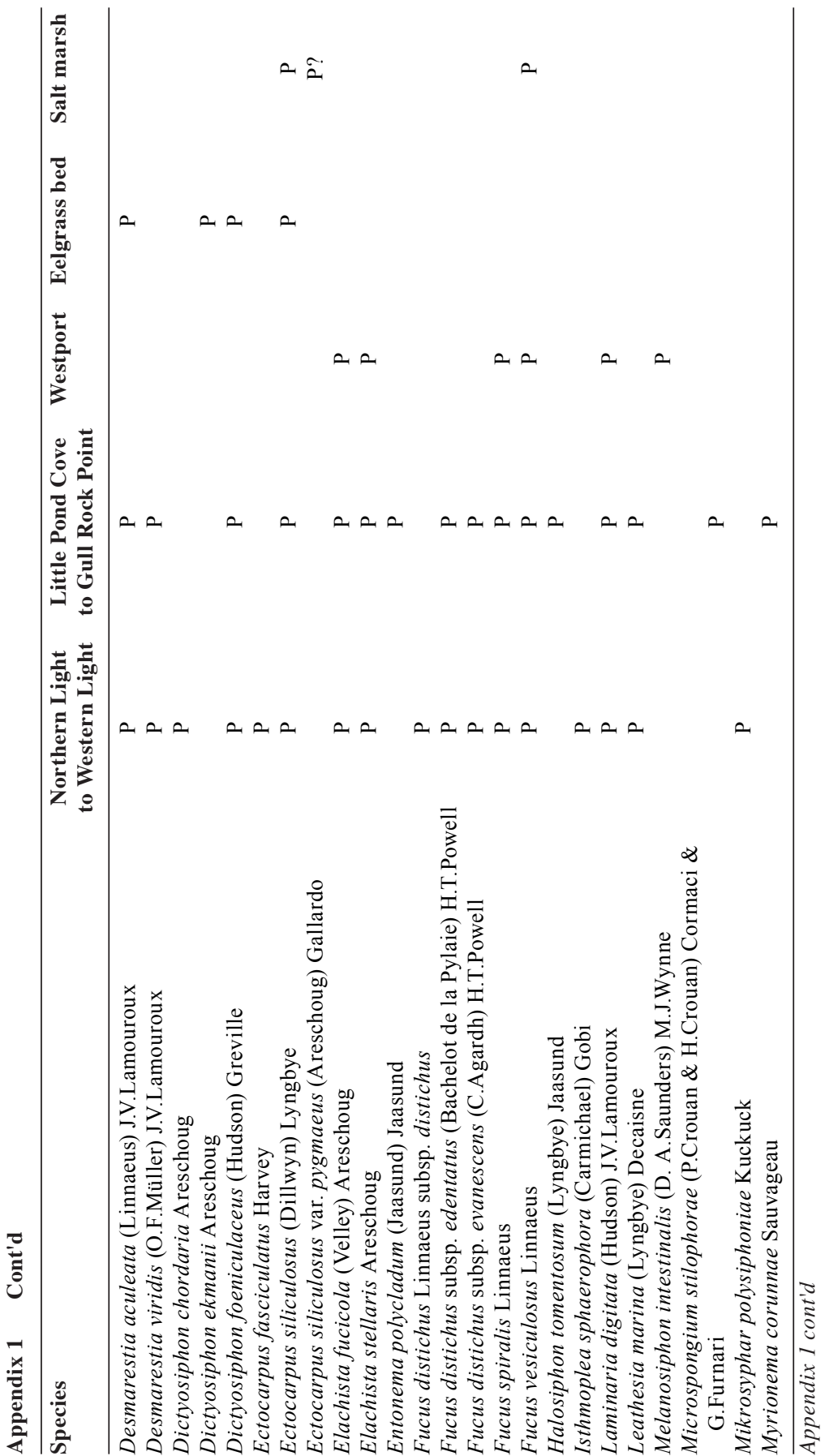




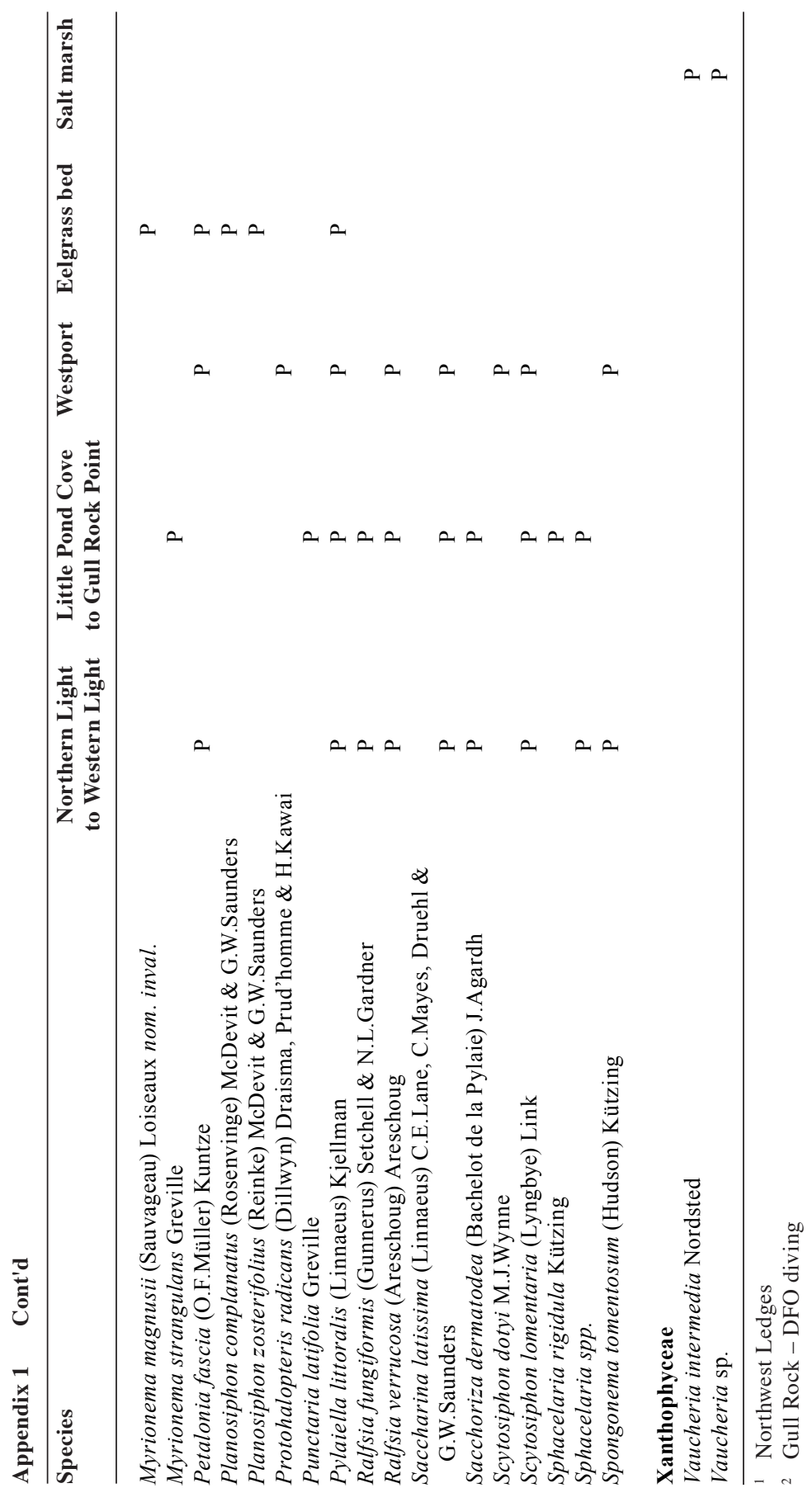


